\title{
Analisis Kinerja Promosi Dan Kinerja Pelayanan Terhadap Nilai Pelanggan Serta Implikasinya Pada Kepercayaan Pelanggan Pest Management: Survey Pada Pelanggan Pest Management Di Wilayah Metropolitan Bandung Raya
}

\author{
Ayi Muhiban, Eddy Jusuf, Popo Suryana \\ Universitas Pasundan, Indonesia \\ Email corresponding author:ayi.3pls@gmail.com
}

\begin{abstract}
ABSTRAK
Penelitian ini bertujuan untuk mengetahui pengaruh Kinerja promosi dan Kinerja pelayanan perusahaan terhadap Nilai Pelanggan serta implikasinya terhadap Kepercayaan pelanggan pest management diwilayah metropolitan Bandung Raya). Populasi dalam penelitian ini adalah pelanggan pest management, sedangkan sampel dalam penelitian ini adalah sebesar 346 responden dengan menggunakan teknik penentuan sampel stratified Purposive Sampling. Untuk menjawab masalah penelitian dan pengujian hipotesis penelitian maka digunakan teknik analisis path. Implikasi manajerial dalam penelitian ini adalah kepercayaan pelanggan pest management diwilayah metropolitan Bandung Raya. Metoda penelitian yang digunakan dalam penelitian ini adalah metode deskriptif analisis dengan populasi sebanyak 2550 pelanggan. Teknik analisis data yang digunakan adalah Teknik Analisis Korelasi untuk mengetahui derajat keeratan hubungan antara variabel. Dengan penelitian dan teknik Analisis Jalur guna mengetahui seberapa besar pengaruh baik langsung maupun tidak langsung. Dalam oprasionalisasinya digunakan bantuan sofware SPSS 22. Hasil penelitian menunjukkan bahwa Kinerja promosi berada pada kategori Kurang, Kinerja Pelayanan berada pada kategori cukup baik, Nilai Pelanggan berada pada kategori kurang dan Kepercayaan pada kategori cukup baik. Hasil penelitian menunjukkan bahwa 1) Kinerja Promosi berpengaruh terhadap Nilai Pelanggan 2) Kinerja Pelayanan perusahaan berpengaruh terhadap Nilai pelanggan, 3) Nilai pelanggan berpengaruh terhadap Kepercayaan, 4) Kinerja Promosi tidak berpengaruh terhadap kepercayaan pelanggan, 5) Kinerja Pelayanan perusahaan tidak berpengaruh terhadap Kepercayaan serta 6) Secara keseluruhan , Nilai pelanggan adalah satu-satunya konstruk yang dapat mempengaruhi pelanggan. Pengaruh Kinerja promosi terhadap nilai pelanggan sebesar 0.191. Pengaruh langsung kinerja pelayanan terhadap nilai pelanggan sebesar 0.286 sehingga pengaruh totalnya 0.477 atau 47,7\% . Pengaruh nilai pelanggan terhadap kepercayaan sebesar 0,819.. menunjukkan koefisien determinasi sebesar 81,9\% dan Pyє 18,1\%, dari variabel Nilai pelanggan terhadap kepercayaan
\end{abstract}

Kata Kunci: Kinerja promosi, Kinerja pelayanan, Nilai pelanggan dan Kepercayaan

\section{PENDAHULUAN}

Jumlah penduduk indonesia pada tahun 2018 mencapai 240 juta jiwa, sehingga Indonesia menjanjikan sebagai tempat investasi yang diminati investor asing. Badan Koordinasi Penanaman Modal mencatat investasi asing (foreign direct investment) yang masuk hingga kuartal kedua tahun 2018 mencapai Rp132,2 triliun, naik sebesar 30,2\% jika dibandingkan periode yang sama pada 2017. Persaingan dalam dunia bisnis diseluruh dunia semakin tinggi dan semakin ketat terlebih khusus di Indonesia, karena setiap perusahaan senantiasa berusaha untuk mendapatkan pangsa pasar yang setiap harinya diharapkan akan selalu bertumbuh.

Perusahaan harus dapat menentukan strategi pemasaran yang tepat agar usahanya dapat bertahan dan memenangi persaingan sekaligus apa yang menjadi tujuan dari perusahaan bisa tercapai. Semakin tingginya persaingan dalam dunia bisnis menjadi indikator bahwa tingkat pertumbuhan penduduk dan tingkat perkembangan pembangunan semakin pesat dan dibalik pertumbuhan pembangunan terdapat sebuah peluang usaha yang sangat menjanjikan.

Dunia industri pariwisata di Indonesia yang makin berkembang pesat ditunjukkan dengan data dari Badan Pusat Statistik Nasional tentang kedatangan wisatawan dari pintu masuk bandara tahun 2017.

Pest Management merupakan bisnis jasa pengendalian hama. Jasa pengendalian hama ini ruang lingkupnya di perkotaan atau pemukiman, hal ini menjadi sangat penting keberadaannya karena bayangkan saja jika kita mengambil contoh sebuah restoran yang di susupi sekawanan 
tikus, lalat, kecoa yang membawa penyakit, bahkan di beberapa kasus kebakaran gedung di sebabkan oleh tikus yang suka mengerat kabel. Dari beberapa masalah ini saja tentu akan membuat kita sebagai konsumen akan langsung mengurungkan niat untuk mendatangi restoran ini. Tidak hanya tikus, rayap juga bisa menggerogoti bagian-bagian bangunan yang terbuat dari kayu yang tentunya bisa mengurangi nilai dan keamanan sebuah bangunan.

Pest Management Operator dituntut untuk terus meningkatkan strategi dalam Kinerja Promosi, Kinerja Pelayanan, Pemasaran Kerelasian Pelanggan, Nilai pelanggan guna meningkatkan kepercayaan pelanggan, meningkatkan kinerja pemasaran tersebut demi profitabilitas dimasa mendatang. Diperlukan pemahaman yang serius dari pihak perusahaan Pest Management Operator terhadap beberapa variabel yang mempengaruhi nilai pelanggan untuk terus meningkatkan kepercayaan.

Berdasarkan pengamatan penelitian di Industri Pest Management di Metropolitan Bandung Raya, penulis mengidentifikasi beberapa permasalahan yang diketemukan, yaitu:

1) Konsumen masih banyak memandang lebih baik mengerjakan sendiri dibandingkan dengan kontrak perusahaan Pest Management

2) Banyaknya yang memutuskan kontrak kerjasama sebelum waktunya habis.

3) Bentuk kerjasama pelanggan banyak kontrak selama 3 bulan.

4) Mudahnya beralih kerjasama dengan perusahaan yang lain.

5) Minimnya pengetahuan masyarakat tentang produk jasa pest management.

6) Kompetensi pegawai pest management masih kurang

7) Karakteristik konsumen yang lebih memilih pada perusahaan Pest Management yang lebih murah.

8) Masih menggunakan produk yang dijual di toko dibandingkan kerjasama dengan pest management.

9) Masih banyak masyarakat yang belum mengetahui manfaat dan tujuan pest management

10) Pesan promosi pest management kurang menarik

\section{TINJAUAN PUSTAKA}

\subsection{Teori Manajemen}

Menurut Plunket, Allen \& Attner (2013:19) menyatakan manajemen adalah "the goals are set and achieved by (the) exercising of related functions - planning,organizing, staffing,leading, and controlling," Definisi manajemen menyatakan bahwa tujuan ditetapkan dan dicapai oleh (yang) menjalankan fungsi-fungsi terkait-perencanaan, pengorganisasian, staffing, memimpin dan mengendalikan). Sedangkan menurut George R. Terry dalam Afifudin (2013:5) mendifinisikan manajemen adalah Suatu proses khas yang terdiri atas tindakan-tindakan perencanaan, pengorganisasian, penggerakan, dan pengendalian yang dilakukan untuk menentukan serta mencapai sasaran yang telah ditentukan melalui pemanfaatan sumber daya manusia dan sumber daya lainnya.

\subsection{Teori Pemasaran}

Untuk sekian lama, pengertian pemasaran sering kali diartikan dengan penjualan dan promosi, walaupun sebenarnya pengertian pemasaran lebih luas dari kegiatan penjualan dan promosi, bahkan sebaliknya penjualan dan promosi adalah sebagian dari kegiatan pemasaran. Managemen Pemasaran menurut Kotler $(2007 ; 7)$ adalah seni dan ilmu memilih pasar sasaran dan mendapatkan, menjaga serta menumbuhkan pelanggan dengan menciptakan, menyerahkan dan mengkomunikasikan nilai pelanggan yang unggul. 
Sedangkan menurut William J Shultz (1961) dalam Alma (2007;130) menjelaskan bahwa managemen pemasaran adalah merencanakan,pengarahan dan pengawasan seluruh kegiatan pemasaran perusahaan ataupun bagian dari perusahaan

\subsection{Teori Kinerja Promosi}

Menurut Kotler dan Armstrong (2014:76) mendefinisikan pengertian promosi sebagai berikut, Promotion refers to activities that communicate to merits of product and persuade target customers to buy it. Sementara menurut Buchari Alma (2016:179) yang mendefinisikan pengertian promosi sejenis komunikasi yang memberi penjelasan yang menyakinkan alon konsumen tetang barang dan jasa dengan tujuan memperoleh perhatian, mendidik, mengarahkan dan menyakinkan calon pembeli. Rambat Lupiyoadi (2013:92) mendefinisikan pengertian promosi adalah kegiatan yang dilakukan perusahaan untuk mengkomunikasikan manfaat produk dan sebagai alat untuk mempengaruhi konsumen dalam kegiatan pembelian atau penggunaan jasa sesuai dengan kebutuhan.

\subsection{Teori Kinerja Pelayanan}

Menurut Mauludin (2013:67) mengemukakan bahwa pelayanan adalah seberapa jauh perbedaan antara kenyataan dan harapan pelanggan atas langganan yang mereka terima atau peroleh. Sedangkan menurut Ivancevich, Lorenzi, Skinner dan Crosby, (2013:2), "pelayanan adalah produk - produk yang tidak kasat mata (tidak dapat diraba) yang melibatkan usaha usaha manusia dan menggunakan peralatan" .Sedangkan Menurut Kotler dalam Lupiyoadi (2014:7) Pelayanan adalah setiap tindakan atau kegiatan yang dapat ditawarkan oleh satu pihak kepada pihak lain, pada dasarnya tidak berwujud dan tidak mengakibatkan perpindahan kepemilikan apapun

\subsection{Teori Nilai Pelanggan}

Menurut Kotler dan Keller (2012:60) "Customer perceived value (CPV) is the difference between the prospective customer's evaluation of all the benefits and all the costs of an offering and the perceived alternatives." Menurut Chen dan Chang (2012) Persepsi nilai memainkan peran penting dalam mempengaruhi niat beli produk ramah lingkungan dan merupakan penentu penting dalam keduanya mempertahankan hubungan pelanggan jangka panjang dan mempengaruhi kepercayaan pelanggan. Menurut Sopiah dan Sangadji, 2013: 180, Nilai pelanggan adalah perbedaan antara total nilai konsumen dengan total biaya yang dikeluarkan konsumen dari pemasaran produk. Perusahaan harus menjadi pusat konsumen dan memberikan nilai yang tinggi pada pasar sasaran. Jumlah nilai bagi konsumen atau pelanggan merupakan akumulasi dari nilai produk, nilai pelayanan, nilai karyawan, dan nilai citra.

\subsection{Teori Kepercayaan}

Kepercayaan didefinisikan oleh Lin dan Lu (2010) sebagai hubungan antara sebuah perusahaan dan konsumen dimana ditunjukkan oleh kepercayaan konsumen pada kemampuan merefleksikan produk dan jasa yang ditawarkan oleh perusahaan secara professional. Lalu menurut Mowen dan Minor dalam Etta Mamang (2013: 201) adalah sebagai berikut: "Kepercayaan konsumen sebagai semua pengetahuan yang dimilki oleh konsumen dan semua kesimpulan yang dibuat oleh konsumen tentang objek, atribut, dan manfaatnya".

Menurut Gunawan (2013) kepercayaan didefinisikan sebagai bentuk sikap yang menunjukkan perasaan suka dan tetap bertahan untuk menggunakan suatu produk atau merek. 
Kepercayaan akan timbul dari benak konsumen apabila produk yang dibeli mampu memberikan manfaat atau nilai yang diinginkan konsumen pada suatu produk

\section{METODE PENELITIAN}

\subsection{Objek Penelitian}

Pelanggan peroarangan Perusahaan Pest Management.sewilayah metropolitan bandung raya

\subsection{Tempat dan waktu Penelitian}

Penelitian ini dilaksanakan dengan mengambil objek penelitian tentang Pengaruh Kinerja Promosi, Kinerja Pelayanan terhadap Nilai pelanggan serta implikasinya terhadap Kepercayaan pelanggan pest management se wilayah metropolitan bandung raya.

\subsection{Populasi}

Populasi adalah kumpulan dari unit sampling yang meliputi satu atau lebih unit unsur (Sekaran, 2000). Responden atau subjek dalam penelitian ini tamu yang menginap pada Pelanggan pest management se wilayah metropolitan bandung raya.Jumlah populasi 2550

\subsection{Sampel}

Menurut Sugiyono (2005) sampel adalah bagian jumlah dan karakteristik yang dimiliki oleh populasi tersebut. Ekosusilo (2005) menyatakan bahwa Winarno Surakhmad menetapkan jika populasinya sejenis (homogen) dan lebih besar dari 100 orang, maka ditentukan sampelnya adalah 50\%. Sedangkan tehnik penentuan sampel yang digunakan adalah secara acak sederhana (Simple Random sampling). Untuk menentukan banyaknya sampel pada penelitian ini menggunakan metode Slovin dengan rumus sebagai berikut:

$$
\begin{aligned}
& \mathrm{n}=\frac{N}{1+N e^{2}} \\
& \text { Keterangan : } \\
& \mathrm{N}=\text { Ukuran populasi } \\
& \mathrm{n}=\text { Ukuran sampel } \\
& \mathrm{e}=\text { Nilai ketelitian yang diinginkan. Besarnya 5\% }
\end{aligned}
$$

Sampelnya sebesar 346 responden

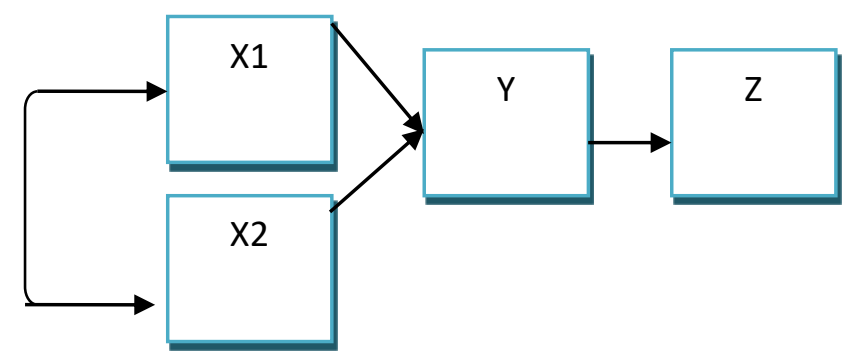

Gambar 1. Struktur Hubungan $\mathrm{X}_{1}, \mathrm{X}_{2}$, terhadap $\mathrm{Y}$ dengan $\mathrm{Z}$ 
Keterangan:

$\mathrm{X}_{1} \quad$ : Kinerja Promosi

$\mathrm{X}_{2} \quad$ : Kinerja Pelayanan

$\mathrm{Y} \quad$ : Nilai Pelanggan

Z : Kepercayaan

$\mathrm{yx} 1$ : Pengaruh Kinerja Promosi $\left(\mathrm{X}_{1}\right)$ terhadap Nilai Pelanggan $(\mathrm{Y})$

$\rho$ yx2 : Kinerja Pelayanan $\left(\mathrm{X}_{2}\right)$ terhadap Nilai Pelanggan $(\mathrm{Y})$

$\rho z y \quad$ : Pengaruh Nilai Pelanggan (Y) terhadap Kepercayaan (Z)

$\varepsilon \quad:$ Epsilon yaitu menunjukkan variabel atau faktor residual yang menjelaskan pengaruh variabel lain yang telah teridentifikasi oleh teori, tetapi tidak diteliti atau variabel lainnya yang belum teridentifikasi oleh teori, atau muncul sebagai akibat dari kekeliruan pengukuran variabel (Kusnendi, 2005)

\subsection{Uji Validitas}

Uji validitas dilakukan untuk memenuhi taraf kesesuaian dan kecepatan alat ukur (instrumen) dalam menilai suatu objek penelitian. Instrumen dikatakan valid apabila mampu mengukur apa yang hendak diukur dan diinginkan dengan tepat. Tinggi rendahnya validitas instrumen menunjukan sejauh mana data yang terkumpul tidak menyimpang dari gambaran tentang variabel yang dimaksud. Menurut Sugiyono, bila korelasi tiap faktor tersebut positif dan besarnya 0,3 keatas, maka faktor tersebut merupakan construct yang kuat (Sugiyono). Untuk mengukur tingkat validitas dari setiap item kuisioner digunakan software SPSS yang merupakan alat ukur dari penilaian

\subsection{Uji Reabilitas}

Reliabilitas adalah tingkat kepercayaan terhadap hasil suatu pengukuran. Pengukuran yang memiliki reliabilitas tinggi merupakan pengukuran yang mampu memberikan hasil ukur terpercaya (reliable). Reliabilitas disebut juga sebagai keterpercayaan, keterendahan, keajegan, konsistensi, kestabilan dan sebagainya. Namun, ide pokok dalm konsep reliabilitas adalah sejauh mana suatu pengukuran terbebas dari kekeliruan pengukuran (measurement error). Koefisien reliabilitas yang besarnya antara 0,7-0,8 dianggap baik untuk digunakan menurut skala Guilford (Kaplan dan Sacuzzo).

Setelah model tersebut memenuhi syarat, maka yang perlu dilakukan selanjutnya adalah uji regression weight/loading faktor. Uji ini dilakukan sama dengan uji t terhadap regression weight /loading faktor/ koefisien model).

\section{HASIL DAN PEMBAHASAN}

\subsection{Analisis deskriftip}

1) Kinerja Promosi berada pada kategori kurang

2) Kinerja Pelayanan berada pada kategori cukup baik

3) Nilai pelanggan berada pada kategori kurang

4) Kepercayaan berada pada kategori cukup baik 


\subsection{Analisis deskriptip}

1. Hubungan Kinerja promosi terhadap Kinerja Pelayanan sebesar :0.512 atau sebesar $51,2 \%$

2. Pengaruh Kinerja promosi Terhadap nilai pelanggan sebesar : 0,191 atau sebesar $19,1 \%$.

3. Pengaruh Kinerja Pelayanan Terhadap nilai pelanggan sebesar: 0,286 atau sebesar $28,6 \%$.

4. Pengaruh Nilai pelanggan Terhadap kepercayaan sebesar: 0,819 atau sebesar $81,9 \%$.

5. Pengaruh kinerja promosi dan kinerja pelayanan Terhadap nilai pelanggan sebesar : 0,477 atau sebesar $47,7 \% \%$

\section{KESIMPULAN}

Berdasarkan hasil pembahasan pada bab sebelumnya mengenai gambaran serta pengaruh Kinerja Promosi, Kinerja Pelayanan dan Pemasaran Kerelasian terhadap nilai pelangga serta implikasinya terhadap kepercayaan pelanggan pest management diwilayah metropolitan bandung raya, dapat di ambil kesimpulan sebagai berikut :

1) Kinerja Promosi berada pada kategori Kurang, hal ini diketahui pula terdapat nilai pernyataan yang paling rendah yaitu mengenai : Kreatifitas perusahaan pest management dalam mengiklankan jasa via telemarketing mempengaruhi keputusan saya dalam memilihnya

2) Kinerja Pelayanan secara keseluruhan dapat digambarkan Cukup Baik, namun demikian masih terdapat nilai pernyataan yang paling rendah yaitu mengenai : Karyawan pest management memiliki kredibilitas yang sangat baik

3) Nilai pelanggan berada pada Kurang, namun demikian masih terdapat nilai pernyataan yang paling rendah yaitu mengenai: Tarip yang dikenakan perusahaan pest management sangat menghemat biaya bagi saya.

4) Kepercayaan berada pada kategori Cukup Baik, namun demikian masih terdapat nilai pernyataan yang paling rendah yaitu mengenai Saya sangat percaya terhadap kompetensi karyawan pest management

5) Kinerja Promosi mempunyai pengaruh terhadap nilai pelanggan pelanggan pest management, dengan total pengaruh sebesar $19,1 \%$

6) Kinerja pelayanan memberikan pengaruh yang sangat besar terhadap Nilai pelanggan dengan total pengaruh sebesar $28,6 \%$

7) Nilai pelanggan memberikan pengaruh yang signifikan terhadap kepercayaan pelanggan pest management dengan total pengaruh sebesar sebesar 0,81 atau sebesar $81,9 \%$. Sedangkan faktor lain yang tidak diteliti dan turut mempengaruhi kepercayaan ditunjukan oleh nilai Py $\varepsilon=0,181$ atau sebesar $18,1 \%$. Variabel lain dimaksud seperti faktor pelayanan, Emotional bonding, Choice reduction and habit, History with company dan lain sebagainya.

8) Kinerja promosi dan kinerja pelayanan Terhadap nilai pelanggan pelanggan pest management dengan total pengaruh sebesar sebesar 0,477 atau sebesar 47,7\% 


\section{DAFTAR PUSTAKA}

Akbar, Mohammad Muzahid and Parvez, Noorjahan. 2009. Impact of Service Quality, Trust, and Custumer Satisfaction on Custumer Loyalty. ABAC Journal.

Akbar, Mohammad Muzahid and Parvez, Noorjahan. 2009. Impact of Service Quality, Trust, and Custumer Satisfaction on Custumer Loyalty.

Basu Swastha Dharmmesta dan Irawan, 2001. Manajemen Pemasaran Moderen. Yogyakarta: FE UGM Cabang Lamabang di Palembang. Jurnal pengaruh pelayanan, Vol. III, No 3.

Bernard H, John \& E.A Russel.2010. Human resources Management: An Experiental Approoach .Edition 4. New York :Mc Graw-Hill Inc.

Chaipoopirutana Sirion, CombsHoward.2010. Efeective Custumer Relationship Management of Health Care : A Study of Perception of Service Quality, Corporate Image, Satisfaction , and Loyalty of Thai Outpatients of Private Hospitals in Thailand. ABBS.

Cohen, David., Gan, Chritopher., Yong, Hua Hwa Au and Choong Esther. 2006. Custumer Satisfaction : Astudy Of Bank Custumer Retention In New Zealand. Commerc Division. ISSN 1174-5045

Consuegra, D., Molina, A., \& Esteban, À. 2007. An Integrated Model of Price, Satisfaction and Loyalty: an Empirical Analysis in Service Sector. Journal of Product \& Brand management.

Dharmmesta, B.S., (1999) Loyalitas Pelanggan: Sebuah Kajian Konsep-tual sebagai Panduan bagi Penalty, Jurnal Ekonomi dan Bisnis Indonesia.

Hardiansyah .2011. Kualitas Pelayanan Publik. Yogyakarta: Gava Media G.R. Terry, 2010. Dasar-dasar Manajemen cetakan ke 16. Jakarta .PT. Bumi kasara.

Hutapea,Parulin \& Thoha,Nurianan,2008.Kompetensi Plus Teori,Desdin,kasus dan penerapan untukHR serta organisasi yang dinamis. Jakarta: Gramedia Pustaka Utama.

Jhon w. Mullins \& Orville C. Walker, Jr (2013:5), marketing is a social process. Journal of Business and Management.

Kadampully, Jay and Hsin-Hui Hu. 2007. Do Hotilier to manage image to Retain Loyal Custumer?.International Journal of Contemporary Hospitality Management.

Kotler, P. dan Keller, K, L. 2007. Manajemen Pemasaran (Bejamin Molan, Pentj). Ed 12, Jilid 1\&2. Jakarta : Indeks. Laohasirichaikul Bunthuwun,

Lichtenstein, D.R., Bloch, P.H. and Black, W.C. (1988), Correlates of price acceptability, Journal of Consumer Research.

Lupiyoadi, 2008, Manajemen Pemasaran Jasa, Jakarta : Salemba Empat

Malau, Harman. (2017). Manajemen Pemasaran. Bandung: CV Alfabeta

Nurmiyati. 2009. Analisis Pengaruh Citra Merek, Kulaitas Produk dan Promosi Penjualan Terhadap Citra Perusahaan. Tesis. Program Studi Magister Manajemen Univesitas Diponegoro Semarang

Ratminto dan Atik Septi Winarsih, 2013, Manajemen Pelayanan, Yogyakarta: Pustaka Pelajar Revitalzation of service quality to Gain Custuer Satisfaction and Loyalty.

RobertL.Mathis and John H.Jackson.2006. Human Resources Manajemen.Jakarta : Selembah empat Jakarta. 
Sutanto, J.E. 2009. Dimension Quality of Service Influence Satisfaction in the Hotel ( A Case study an examination of the transaction Model in Service Industry). ISSN: 1978-774X Proceeding, International Seminar on Industrial Engineering and Management.

Violeta Saladiene, Dalius Skindaras.2009. The Relationship Between Price and Loyalty in Services Industry. ISSN 1392 -2785 Inzinerine Ekonomika-Engineering Economics(3). 2009.

Wirtz, J., \& Kimes, S. E. (2007). The Moderating Role of Familiarity in Fairness Perceptions of Revenue Management Pricing”. 